\title{
Public investment for sustainable growth - managing subnational risks
}

EHTISHAM AHMAD, Ph.D.*

Conference keynote**

https://doi.org.10.3326/pse.41.2.1

\footnotetext{
* This paper is based on a keynote delivered at the conference Public Sector Economics organized by the Institute of Public Finance and Friedrich-Ebert-Stiftung in Zagreb on October 14-15, 2016 and the Annual Development Lecture at Peking University, in December 2016. I thank participants for helpful comments. All errors are mine.

${ }^{* *}$ Received: May 17, 2017

Accepted: May 25, 2017

\section{Ehtisham AHMAD}

London School of Economics and Political Science, Houghton Street, London WC2A 2AE, UK University of Bonn, Regina-Pacis-Weg 3, 53113 Bonn, Germany

Zhejiang University, 866 Yuhangtang Road, Hangzhou, Zhejiang Province, 310058, P. R. China e-mail: s.e.ahmad@1se.ac.uk ORCID iD: 0000-0002-6054-3336
} 


\section{THE CONTEXT}

The new global emphasis on public infrastructure for connectivity builds on the declarations of the UN Sustainable Development Agenda, and most recently the Belt and Road Initiative that seeks to connect global economies and recreate old trading links and generate new ones. Infrastructure also holds the key to addressing the Middle-Income Trap, along with education and innovation. Yet, there is considerable evidence from the EU, Latin America and China to show that while the advantages of connectivity investment are significant and necessary, in isolation these are far from sufficient in ensuring more inclusive and sustainable outcomes.

Sustainable growth involves private investments that are channeled to the most promising and productive activities. Of course, firms respond to price signals, but with imperfect or incomplete information, tend to reinforce existing profit centers where the jobs tend to be concentrated (London, Barcelona, Milan, Shanghai, Guangzhou-Shenzhen, Santiago de Chile), typically resulting in increasing inequality, congestion and pollution. The resulting conurbations attract migrants, and in large metropolitan areas in Latin America and South Asia, there is a sharp increase in informality that leads to incentives for cheating that result in low productivity (see Levy, 2008). Regional connectivity may not always result in a more equal or level playing field and in the cases mentioned above may have exacerbated imbalances and inequalities. As seen in the UK, which has experienced a strong recovery since the 2008 crisis, the Brexit vote suggests that there may be a political backlash if employment and income generation, or adjustment costs, are not more evenly distributed.

In this paper, we argue that a combination of instruments is likely to be needed at both national and local levels, including tax handles, and full information, particularly involving liabilities within an intertemporal framework, to ensure sustainable and inclusive development. Since most of the policies are implemented at the sub-national level, local financing, institutions and incentives affect the possibility of creating new "growth hubs" or clean and efficient cities that are needed for sustainable growth. We draw on evidence from the EU, China and Chile, which is considered by the IFIs as one of the leading countries as far as investment management is concerned. We also use empirical illustrations based on the theory of reform applied to the Chilean case to illustrate how to improve on the investment allocations that are already praised as arms-length by the Bretton Woods Institutions, to develop a sustainable growth strategy that also addresses the middleincome trap. This has wider applications in Europe, and China, and in the implementation of the Belt and Road Initiative.

\section{SOME EU EXAMPLES}

The role that public investment may have in encouraging cross-border and regional connectivity has long been a focus of EU policy. Structural funds have been used to finance transport links - including in Motorways and High Speed rail links. This is to facilitate the encouragement of private sector investment and activities to generate employment opportunities. 
One of the main components of a sustainable development strategy is based on clean new cities, or revamped older cities, at some distance from the existing metropolitan hubs. As the EC experience shows, connectivity is necessary but not sufficient in creating hubs.

The UK has some of the best connectivity in Europe, with North-South train and motorway links, as well as international airports. However, as the recent Eurostat report shows, this has not been sufficient to prevent the highest inequality among European cities - by far exceeding that in any other country on the Continent. The connectivity only increased the migratory pressures towards the capital, London. It also explains the Brexit vote in England and Wales, except for London which benefitted from and voted overwhelmingly to stay in the EU.

In the UK, overall growth over the past decade was facilitated by the growth of the financial services industry, particularly in the Greater London area. However, this did not compensate for the failing coal industry in Wales (despite funding from the EC), or the defunct shipbuilding and textiles in the North of England and virtual closure of the automobile industry in the Midlands. The political backlash was felt only with the Brexit vote that took the government by surprise.

Similarly, in Italy, the development of the services sector in Milan has not compensated for the closure of the automobile and textile sector in nearby Turin. Further, the investment in the North-South high speed train and Autostrada links, between Turin to Milan to Rome to Naples has not resulted in rebalancing, e.g., in Turin or in Naples. It just means that it is easier for people to commute from Turin to Milan. Regional inequalities continue to increase, with the lagging South of Italy severely constrained in using the new infrastructure or attracting complementary privatesector investment (see e.g., Ahmad, Bordingnon and Brosio, 2016).

In many cases, local governments have tried to capitalize on perceived rents associated with the infrastructure projects, often to engage in real estate or tourism development. This has been facilitated by poor accounting for PPPs, as well as an ability to hide transactions by contracting from local banks (see e.g., the case of Madeira). The hidden liabilities exacerbated the extent and depth of the crisis. And, as in Spain and Ireland, private liabilities were quickly transformed into public liabilities as the crisis hit, forcing a public charge to rescue the local cajas (banks).

It is by no means certain that new connectivity will lead to additional activity and employment in depressed areas, and further imbalances are possible without additional local investments and enhanced service delivery. The lessons from the crisis in Europe are that local accountability matters, both in terms of own-source revenues and effective service delivery for the generation of sustainable hubs. Further, full information on transactions, including PPPs, is needed to avoid rentseeking behavior and game play across levels of government. Without full information (e.g., local balance sheets consistent with the GFSM2014 standard), 
neither yardstick competition, nor effective implementation of subnational fiscal rules can be assured. In this regard, the absence of EU standards and requirements for information generation pose a significant problem, including for the private sector. Risk management becomes more complicated as private liabilities can be transformed into public debt in a very short period of time.

The EU experience is of relevance for the SDG investment agenda, as well as the Belt and Road initiative.

\section{SOME CHINESE PERSPECTIVES}

The 1993/4 reforms focused on a centralization of tax instruments in a newly created (central) State Administration of Taxation (SAT), with a sharing of the VAT, and an equalization transfer system. However, a "revenue-returned" component provided the basis for the consolidation and expansion of the "coastal hubs", because of the limited connectivity infrastructure inland. Given the relatively low, albeit relatively equally distributed individual incomes in the aftermath of the Cultural Revolution, an increase in income dispersion was a consequence of the growth process and a driving factor for the migration to the coastal hubs (see Ahmad and Wang, 1991). While this strategy was criticized by some of China's Development Partners as likely to generate spatial inequalities, it was the only feasible mechanism to maintain double digit growth over two decades, and provide more or less full employment opportunities with improving productivity and enhanced complexity of the economy. Over 150 million workers released from agriculture and low value added activities in the interior of the country moved to more productive activities along the coast. And over 700 million people were taken out of poverty in two decades (out of a global total of around 750 million during this period) driven by the strategy of developing the coastal "hubs".

However, widening personal income and regional disparities pose problems for the long-term sustainability of the Chinese development strategy. As pointed out in IMF (2016), the increase in the Chinese level of inequality has been particularly high - rising from around 0.4 in 1992 to around .52 in 2013. This is now at levels in the market-based emerging economies in Latin America, such as Chile, that have relied on the service sector to generate additional employment opportunities. Given the implicit social contract in China, high levels of inequality are likely to be less sustainable than in Chile, although the absence of adequate employment opportunities have begun to pose problems in Chile.

A major consequence of the success of the coastal hub phenomenon in China (as in Chile) is the high level of pollution and congestion in the metropolitan areas, e.g., Beijing, Guangzhou-Shenzhen, Hangzhou-Shanghai corridor. The congestion makes it costlier to do business. And rising pollution levels seriously degrade the quality of life. Beijing's fine particle air pollution level remains well above acceptable health standards despite constant high-level political attention that has led to some improvement in recent years. 
A part of the solution to the problems of success in the coastal growth strategy is to move production inland, closer to population concentrations and sources of raw materials, through the creation of smaller inland urban "hubs" that are less dependent on fossil fuels for transportation needs and where the choice of techniques adequately reflects social costs and benefits. The existing metropolitan areas could then be transformed into clusters of "clean" high-tech and service sectors.

The Chinese "Western region development strategy" over the past decade, however, had limited success, largely because of the higher cost of production and exports. The cost-differential will change with the enhanced public investment in cross-border connectivity with the Belt and Road links to the Middle East, Central Asia, Africa and Europe. Just the opening-up of existing rail and road links have made it possible for the first train from Zhejiang province to arrive in Teheran in 14 days using the Western Khorgos hub, as opposed to the 45 days it takes by the sea route. This is significant in view of the rapidly increasing trade between the two countries, increasing from $\$ 4$ bn in 2003 , to $\$ 51$ bn in 2014 , and projected to increase to $\$ 600 \mathrm{bn}$ in ten years. The deep-sea port of Gwadar, along with road, rail and pipeline links with Xinjiang will similarly open the markets in the Middle East and East and North Africa - eliminating the cost disadvantages faced by the Chinese interior provinces vis à vis the coastal hubs.

The creation of new internal hubs in China has been constrained by the absence of adequate instruments - this includes own-source revenues at the local level, with the failure of the property tax experiments in Shanghai and Chongqing - and full information on local transactions and the buildup of liabilities (see Ahmad and Zhang, 2017). While a system of local bonds has been introduced, with-

out the anchor of own-source local revenues, it is unlikely to provide the right incentives to markets, or resolve the issue of local liabilities in an inter-temporal perspective, or to make for sustainable new hubs.

\section{PUBLIC INVESTMENT FOR SUSTAINABLE GROWTH}

\subsection{METHOD}

The use of economy-wide shadow prices ${ }^{1}$ allows for the general effects of public interventions to be assessed, shedding light on the sectors more suitable for reforms, taking into account effects on households, producers, and government. Given that a range of shadow prices is feasible, a choice based on government preferences for a clean economy and inclusive growth should be the basis for the specific choice of shadow prices. This is then reflected in the consistent selection of projects at the national and local levels - leading to the choice of sustainable hubs and employment generation.

Following Drèze and Stern (1987) and Ahmad and Stern (1991), the government assesses projects based on preferences among different states of the economy reflecting valuations of environmental costs, as well as distributional characteris-

\footnotetext{
${ }^{1}$ See Drèze and Stern (1987).
} 
tics. The decisions are made based on maximizing a welfare function subject to market clearing restrictions and evaluated at shadow prices. The planners' objective function (V) takes the Bergson-Samuelson form, and the social welfare function depends on household consumption levels. Consumption is a function of prices, income, taxes, and demand and supply constraints. Therefore, the aggregated utility of any project is calculated as the welfare-weighted sum of individuals' marginal willingness to pay for the project. The objective function can be more general and include a variety of objectives that reflect the government's perspectives, say, on environmental damage.

$$
\operatorname{Max} V(s, w), \text { subject to } E(s, w)=z
$$

$V(s, w)$ is the social welfare function, which depends on endogenous variables $(s)$ and exogenous variables $(w)$. The maximization problem can be solved using the Lagrangian:

$$
L(s, w)=V(s, w)-v^{\prime}[E(s, w)-z]
$$

where $v^{\prime}$ represents the shadow price or the increase in the value of social welfare function when an extra unit of public output is available (the social opportunity cost). The first order conditions to maximize the function imply that the net effect on welfare due to variations in $(s)$ or $(w)$ includes the costs related to changes in demand evaluated at shadow prices.

$$
d V=\frac{\partial V}{\partial w} d w+\frac{\partial V}{\partial s} d s=\left[\frac{\partial V}{\partial w}-v^{\prime} \frac{\partial E}{\partial w}\right] d w
$$

Once the vector of responses is defined, it is possible to assess how private agents would respond (which is reflected in changes in net demand and supply) and the consequent effects on their utility function.

The shadow cost, $v^{\prime} \frac{\partial E}{\partial w}$ of the extra demand can also be represented as the difference between $p^{\prime} y$ (actual profits) and $q$ 'x (household expenditures), which represents government tax revenues $\left(R_{v}\right)$. The shadow cost may be rewritten as

$$
d V=\left[\frac{\partial V}{\partial w}+\frac{\partial R_{v}}{\partial w}\right] d w
$$

The total effect on welfare can be seen as the direct change in welfare plus the change in shadow revenue, representing the general equilibrium adjustments associated with the reform. This method can be used in a broad set of applications, and for this case, including tax reforms as shown by Ahmad and Stern (1984). In this case, changes in $w$ would be represented as changes in a vector $t$ or taxes on goods.

$$
d V=\left[\frac{\partial V}{\partial t}-v^{\prime} \frac{\partial x}{\partial t}\right] d t
$$


Considering derivatives hold lump-sum incomes constant, and that $q=p-t$, and assuming that producer prices are proportional to shadow prices equation (5) can be rewritten as:

$$
\begin{gathered}
d V=\left[\frac{\partial V}{\partial t}-\gamma \frac{\partial}{\partial t}\left(t^{\prime} x\right)\right] d t \\
\frac{\partial V}{\partial t}-\gamma \frac{\partial}{\partial t}\left(t^{\prime} x\right)>0
\end{gathered}
$$

If equation (7) is greater than 0 , social welfare is increased by raising the $i^{\text {th }}$ tax or increasing its price. Declines in social welfare are offset by the extra revenue raised.

The value of $\gamma$ can be used to identify directions of reform.

$$
\gamma_{i}=-\frac{\frac{\delta V}{\delta t_{i}}}{\frac{\delta R}{\delta i_{i}}}
$$

$\frac{\delta V}{\delta t_{i}}=-\sum_{h} \beta^{h} x_{i}^{h}$, where $\beta^{h}$ represents the social marginal utility of income for households, and $x_{i}$ is demand for commodity $i$ by household $h$, and $\frac{\delta R}{\delta i_{i}}=-\sum v_{j} \frac{\delta x_{i}}{\delta t_{i}}$ can be represented as variations in consumption due to changes in taxes or public supplies at shadow prices.

This method has the advantage of incorporating the degree of inequality aversion in the welfare function by assigning different weights to the additional consumption by groups at different levels of income. A high degree of interpersonal inequality aversion is also expected to favor lagging regions. The effects of a project on the welfare function depend on the social marginal utility of household expenditures and the demand for each commodity by households.

While there are several ways to estimate the welfare weights, this proposal uses the method proposed by Ahmad and Stern (1984). The welfare weights are normalized to the welfare weight for the poorest household (unity) and adjusted by an inequality aversion parameter so that a marginal expenditure by the rich is less valuable than that by the poor.

$$
\beta^{h}=\left(\frac{I^{1}}{I^{h}}\right)^{e}
$$

$I^{\mathrm{h}}$ is the per-capita expenditure of the $h^{\text {th }}$ household and $I^{1}$ is the normalized welfare weight of the poorest household. Therefore, $\beta^{h}$ represents the marginal social value of a unit of expenditure to household $h$ relative to household 1 . The parameter $e$ represents the Atkinson inequality aversion parameter, where $e=0$ implies 
that a unit of income to the richest is seen as equivalent to a unit received by the poorest; $e=1$ indicates that, if $I^{\mathrm{h}}$ is twice $I^{1}$ then a marginal unit to $h$ is worth half that to household 1 , and so forth.

Applying Drèze and Stern (1987) and the related theory of reform enunciated by Ahmad and Stern $(1984,1991)$ requires:

- market prices to be converted to the shadow prices needed to assess sectoral social profitability. The method extends the Little and Mirrlees (1974) approach; and

- the corresponding changes in taxes/relative prices that need to generate and support welfare-improving structural reforms to be evaluated using estimates of household responses.

The Ahmad and Stern $(1984,1991)$ and Drèze and Stern (1987) methods permit different scenarios using different inequality aversion parameters. The shadow prices also permit a set of additional objectives linked, for example, to a sustainable development agenda.

The accounting ratios calculated to incorporate inequality aversion parameters given by equation (9) and the cross-industry effects by using economy-wide shadow prices generate alternative patterns of public investment allocations. Accounting ratios linked to the development agenda, and estimated taking into account general effects on the economy, should favor economic convergence and sustainable growth.

In addition, economy-wide accounting ratios provide directions for tax reform, giving policymakers a tool that links government revenues and the effects of consumption and production patterns, and generates incentives for good governance. The tax reforms are needed to "lock" in place the incentives facing key actors in the economy - including firms and households. The tax reforms, such as for local own-source revenues, also require an equalization transfer framework to enable all regions to provide similar levels of service at similar levels of tax effort, to facilitate effective local service delivery in the new growth hubs. An equalization framework was adopted in China following the 1994 reforms, but does not apply in Chile or most Latin American countries.

\subsection{ILLUSTRATIONS FOR CHILE}

Over the past two decades, Chile has been among the top Latin American performers in terms of macroeconomic management - with a low stock of debt $(21 \%$ of GDP, which involved a doubling since 2010), low deficits, a SWF, tax/GDP ratio of around $18 \%$ - or within the range suggested for the MDGs, and a privatesector oriented policy stance. This is bolstered by the arms-length and uniform approach to public investment, through the National Investment System (SNI), and a transparent procurement process, Chile Compras - both praised by the IFIs as being examples of how to manage the public investment process. 
Growth has exceeded that in neighboring countries, including during the crisis period since 2010 (IMF, 2016). It has also led to significant overall reductions in poverty over a twenty-year period. However, the growth has been largely sustained by commodity exports, especially copper and agricultural raw materials, especially to China in the recent decade, offsetting declining productivity growth. The result has been what President Ricardo Lago (2013) called the "middle income trap". As is common in primary commodity exporting countries, there has been limited development of domestic linkages. This is reflected in the very limited economic complexity, lower than it was twenty years earlier, and is symptomatic of the greater reliance on primary commodity exports and a Dutch Disease effect. In relative terms, the negative value of the economic complexity index shows that the full economic potential has not been realized (Hausman et al., 2016). This has left the country exposed to external shocks, and Chile is particularly vulnerable to shifts in demand for its copper exports, especially from China (IMF, 2016). This clearly has an impact on the pattern of employment opportunities, and social cohesion.

Another consequence of the growth and investment strategy is the concentration of activities in the ports, and Metropolitan zone, including Santiago, despite the investment of the North-South Highway. Regional disparities are high, and there is increasing congestion and pollution in the Metropolitan Zone. Migrants from the less well-off regions head to the Metropolitan Zone, because that's where the jobs are, given the limited diversification of the economy to provide sustainable employment generation. This causes crowding in peripheral shantytowns with poor facilities, including for education and other public services. A striking characteristic of Chile is the increasing concentration and population pressure in the Metropolitan areas. This also results in choking growth potential and contributing to the middle-income trap.

The regional imbalances also led to persistent pockets of poverty in the lagging regions. There was an increasing incidence of poverty in 20 of 26 functional urban areas, ${ }^{2}$ again with a clear regional pattern. More worryingly, the largest concentration of the poor ( $40 \%$ of the total) is in the Metropolitan area, although it has the highest per capita incomes and employment opportunities. The income inequalities are magnified by the inequalities in access to public services (CASEN, 2015). This is also reflected in the provision of tertiary education, for which there is limited public funding. Consequently, interpersonal inequalities are also increasing, the Gini coefficient in Chile well above the OECD levels. ${ }^{3}$ Addressing interpersonal inequalities depends on a more effective operation of the personal income tax. Given its poor performance in Latin America, generating additional third party information from asset holding, particularly property, suggests the importance of a regional/local surcharge or "piggy-back". However, for this not to widen inter-regional inequalities, an equalization framework is needed (Ahmad, Letelier and Ormeño, 2016 and forthcoming).

\footnotetext{
${ }^{2}$ See OECD (2013).

${ }^{3}$ IMF (2013).
} 
Regional connectivity, in the form of the North-South Highway in Chile is important and will certainly play a major role in the future. However, it has not reduced regional inequalities, as the preconditions for local "hubs" outside the Metropolitan areas are not met - including the provision of basic services and adequate own-source financing to generate incentives for the local governments to provide adequate supporting infrastructure for private sector activities. This reflect the problems have been observed with the connectivity infrastructure in the EU - e.g., in Spain and Italy - as described above. Without the creation of the new "hubs", or clean new cities, regional inequalities might increase.

The recent development of solar energy in Chile, providing some of the cheapest forms of clean power, also open-up the potential for generating new hubs, if the local preconditions are created. The Chilean examples also have some relevance for the rebalancing in China, and the Belt and Road Initiative focusing on crossborder connectivity in Asia and Africa.

\section{DISEQUALIZING ROLE OF INVESTMENT ALLOCATIONS?}

Chile's national system of investment appraisal, SNI, vets all public projects. This performs well against the investment criteria of the IFIs (see assessment for Chile in World Bank, 2006). However, the project selection criteria are largely based on market criteria (see table 1) - including interest rates and accounting rations that do not take adequate account of externalities, or inequalities. There is an attempt to incorporate the cost of carbon emissions, but without full economy-wide implications. It is not surprising that market based criteria would lead to a concentration of activities in the most profitable sectors and in regions that are well endowed with connectivity and public services. The public investment could be complementing private sector activities in the more advanced regions, leading to the migration to the Metropolitan areas and greater inequality in employment opportunities and incomes, as well as in the access to public services as pointed out above.

\section{TABLE 1}

SNI project selection parameters

\begin{tabular}{|c|c|}
\hline Goods/inputs & Conversion factor \\
\hline Social discount rate & $6 \%(8 \%$ and $12 \%$ in previous years $)$ \\
\hline Exchange rate & 1.01 \\
\hline Emissions $\left(\mathrm{CO}_{2}\right)$ & 2.213 pesos per ton of equivalent carbon emission \\
\hline Land & Market value (without any correction) \\
\hline $\begin{array}{l}\text { Domestic goods } \\
\text { and inputs }\end{array}$ & Market value - VAT \\
\hline Importable materials & (Market value-duties) x currency conversion factor \\
\hline Fuels & Depends on type of fuel and vehicle \\
\hline High-skill labor & Market value $\mathrm{x}$ factor of conversion for high-skilled labor $(0.98)$ \\
\hline Medium-skill labor & Market value $\mathrm{x}$ factor of conversion for mid-skilled labor $(0.68)$ \\
\hline Low-skill labor & Market value $\mathrm{x}$ factor of conversion for low-skilled labor $(0.62)$ \\
\hline $\begin{array}{l}\text { General expenses } \\
\text { and profits }\end{array}$ & Market value - VAT \\
\hline
\end{tabular}

See Ahmad and Viscarra (2016). 
The complexity analysis suggests the need for diversification but does not clarify what sectors should be pursued or where, or the role of public policy in achieving this. We focus here on the role of economy-wide shadow prices, drawing on Ahmad and Viscarra (2016) and follow-up work with the SNI supported by the InterAmerican Development Bank.

\section{ENHANCING THE SNI}

We draw here on work with the SNI to make the investment system more reflective of the sustainable development and climate change agenda that both the current Bachelet Administration and its predecessor have subscribed to (see Ahmad and Viscarra, 2016). Project choices and tax/public pricing decisions are inextricably linked and this is seen most clearly with environmental concerns, and income distribution.

The method permits the examination of economy-wide or inter-industry effects of changes in public supplies or taxes/public prices. It also facilitates the potential effects on households in different circumstances and on firms. While this is at the heart of the theory of reform (and is much simpler to estimate than an optimal tax framework) it can form the basis for an evaluation of gainers and losers needed for a political economy assessment that also includes governments at different levels. While the institutional arrangements vary from country to country, and must be kept in mind, the approach is general enough to be applicable in Chile, Senegal, India or Pakistan, or even China.

In principle, there are a multitude of shadow prices corresponding to various assumptions about traded (importables or exportables) and non-traded goods, the marginal social cost of public funds, and the accounting ratios for different types of labour, capital, and land.

Ahmad and Viscarra (2016) illustrate the method of economy-wide shadow prices for Chile and examine what happens with a number of permutations in the key variables (some of the variance in Accounting Ratios (ARs) is reported in table 2 for a set of scenarios based on assumptions concerning sectors (IM, EX and NT) and factor inputs.

It is clear from the table 2 that the precise assumptions used will matter in relation to the resulting sectoral accounting ratios, and hence the choice and rankings of the projects to the chosen. While there are clear differences across the sets of assumptions, the general pattern emerging from the simulations is that the highest accounting ratios are for the higher linkage (especially in terms of potential employment generation, and higher value added sectors). This is consistent with the Hausman et al. Complexity story for Chile, that suggests the importance of diversification. The economy-wide shadow prices indicate some priorities for public action. This is also reflected in the corresponding social profitability exercise (table 3 ). 
TABle 2

Accounting ratios, sensitivity analysis

\begin{tabular}{|c|c|c|c|c|c|c|c|c|c|c|}
\hline \multirow[b]{2}{*}{ Groups } & \multirow[b]{2}{*}{$\frac{\tilde{E}}{0}$} & \multicolumn{3}{|c|}{$\mathrm{K}=\mathbf{0 . 8 1}$} & \multicolumn{3}{|c|}{$K=0.5$} & \multicolumn{3}{|c|}{$K=0.25$} \\
\hline & & $\begin{array}{l}\mathbf{L}=\mathbf{0 . 3 7} \\
\mathrm{M}=\mathbf{0 . 4 0} \\
\mathrm{H}=\mathbf{0 . 7 0} \\
\end{array}$ & $\begin{array}{l}\mathrm{L}=\mathbf{0 . 6 2} \\
\mathrm{M}=0.68 \\
\mathrm{H}=\mathbf{0 . 9 8} \\
\end{array}$ & $\begin{array}{l}L=0.87 \\
M=0.90 \\
H=1.00 \\
\end{array}$ & $\begin{array}{l}L=0.37 \\
M=0.4 \\
H=0.7 \\
\end{array}$ & $\begin{array}{l}L=0.62 \\
M=0.68 \\
H=0.98 \\
\end{array}$ & $\begin{array}{l}L=0.87 \\
M=0.90 \\
H=1.00 \\
\end{array}$ & $\begin{array}{l}\mathbf{L}=\mathbf{0 . 3 7} \\
\mathrm{M}=\mathbf{0 . 4 0} \\
\mathbf{H}=\mathbf{0 . 7 0} \\
\end{array}$ & $\begin{array}{l}L=0.62 \\
M=0.68 \\
H=0.98 \\
\end{array}$ & $\begin{aligned} & L=0.87 \\
& M=0.93 \\
& H=1.00 \\
&\end{aligned}$ \\
\hline $\begin{array}{l}\text { Flour, pasta, } \\
\text { cereals }\end{array}$ & IM & 0.986 & 0.986 & 0.986 & 0.986 & 0.986 & 0.986 & 0.986 & 0.986 & 0.986 \\
\hline Vegetables & EX & 0.934 & 0.929 & 0.929 & 0.935 & 0.931 & 0.93 & 0.936 & 0.932 & 0.932 \\
\hline Fruits & EX & 0.541 & 0.538 & 0.537 & 0.542 & 0.539 & 0.539 & 0.543 & 0.54 & 0.539 \\
\hline Meats, sausages & $\mathrm{IM}$ & 0.988 & 0.988 & 0.988 & 0.988 & 0.988 & 0.988 & 0.988 & 0.988 & 0.988 \\
\hline $\begin{array}{l}\text { Dairy products, } \\
\text { cheese, eggs }\end{array}$ & NT & 0.988 & 1.134 & 1.208 & 0.954 & 1.074 & 1.174 & 0.927 & 1.047 & 1.147 \\
\hline Edible oils, fats & $\mathrm{IM}$ & 0.987 & 0.987 & 0.987 & 0.987 & 0.987 & 0.987 & 0.987 & 0.987 & 0.987 \\
\hline $\begin{array}{l}\text { Fish, } \\
\text { crustaceans, } \\
\text { mollusks }\end{array}$ & EX & 0.985 & 0.982 & 0.981 & 0.986 & 0.983 & 0.982 & 0.987 & 0.984 & 0.983 \\
\hline Animal feed & NT & 0.635 & 0.755 & 0.86 & 0.611 & 0.73 & 0.836 & 0.591 & 0.711 & 0.816 \\
\hline Fuels & IM & 0.991 & 0.991 & 0.991 & 0.991 & 0.991 & 0.991 & 0.991 & 0.991 & 0.991 \\
\hline $\begin{array}{l}\text { Other food } \\
\text { products }\end{array}$ & IM & 0.977 & 0.977 & 0.977 & 0.977 & 0.977 & 0.977 & 0.977 & 0.977 & 0.977 \\
\hline Liquor & EX & 0.961 & 0.953 & 0.952 & 0.965 & 0.956 & 0.955 & 0.967 & 0.958 & 0.957 \\
\hline $\begin{array}{l}\text { Non-alcoholic } \\
\text { beverages }\end{array}$ & NT & 0.550 & 0.661 & 0.682 & 0.513 & 0.625 & 0.645 & 0.484 & 0.595 & 0.616 \\
\hline Tobacco & NT & 0.464 & 0.556 & 0.585 & 0.437 & 0.529 & 0.558 & 0.415 & 0.507 & 0.536 \\
\hline $\begin{array}{l}\text { Textiles, } \\
\text { clothing, } \\
\text { footwear }\end{array}$ & IM & 0.982 & 0.982 & 0.982 & 0.982 & 0.982 & 0.982 & 0.982 & 0.982 & 0.982 \\
\hline $\begin{array}{l}\text { Material for } \\
\text { conservation, } \\
\text { repair of } \\
\text { dwelling }\end{array}$ & IM & 0.949 & 0.949 & 0.949 & 0.949 & 0.949 & 0.949 & 0.949 & 0.949 & 0.949 \\
\hline $\begin{array}{l}\text { Stationery, } \\
\text { office supplies }\end{array}$ & EX & 0.975 & 0.969 & 0.968 & 0.977 & 0.971 & 0.97 & 0.978 & 0.973 & 0.972 \\
\hline $\begin{array}{l}\text { Printing, } \\
\text { publishing }\end{array}$ & NT & 0.653 & 0.846 & 1.014 & 0.63 & 0.823 & 0.991 & 0.611 & 0.805 & 0.973 \\
\hline $\begin{array}{l}\text { Pharmaceutical } \\
\text { products }\end{array}$ & NT & 0.678 & 0.856 & 0.888 & 0.652 & 0.829 & 0.861 & 0.631 & 0.808 & 0.84 \\
\hline $\begin{array}{l}\text { Toiletries, } \\
\text { cosmetics }\end{array}$ & NT & 0.847 & 1.064 & 1.098 & 0.827 & 1.044 & 1.078 & 0.811 & 1.028 & 1.062 \\
\hline $\begin{array}{l}\text { Glassware, } \\
\text { crystal, } \\
\text { tableware, } \\
\text { household } \\
\text { utensils }\end{array}$ & NT & 0.535 & 0.639 & 0.65 & 0.498 & 0.602 & 0.613 & 0.468 & 0.572 & 0.583 \\
\hline $\begin{array}{l}\text { Electronic } \\
\text { artifacts, large } \\
\text { size tools, } \\
\text { equipment for } \\
\text { the household }\end{array}$ & NT & 0.664 & 0.83 & 0.853 & 0.644 & 0.81 & 0.833 & 0.627 & 0.794 & 0.817 \\
\hline $\begin{array}{l}\text { Electronic } \\
\text { artifacts, small } \\
\text { size tools, } \\
\text { equipment for } \\
\text { the household }\end{array}$ & NT & 0.692 & 0.853 & 0.87 & 0.675 & 0.837 & 0.853 & 0.662 & 0.824 & 0.84 \\
\hline Furniture & NT & 0.655 & 0.847 & 1.012 & 0.592 & 0.785 & 0.95 & 0.542 & 0.735 & 0.899 \\
\hline
\end{tabular}




\begin{tabular}{|c|c|c|c|c|c|c|c|c|c|c|}
\hline \multirow[b]{2}{*}{ Groups } & \multirow[b]{2}{*}{$\stackrel{\tilde{v}}{0}$} & \multicolumn{3}{|c|}{$K=0.81$} & \multicolumn{3}{|c|}{$K=0.5$} & \multicolumn{3}{|c|}{$K=0.25$} \\
\hline & & $\begin{array}{l}\mathrm{L}=\mathbf{0 . 3 7} \\
\mathrm{M}=\mathbf{0 . 4 0} \\
\mathrm{H}=\mathbf{0 . 7 0}\end{array}$ & $\begin{array}{l}\mathrm{L}=\mathbf{0 . 6 2} \\
\mathrm{M}=\mathbf{0 . 6 8} \\
\mathrm{H}=\mathbf{0 . 9 8}\end{array}$ & $\begin{array}{l}\mathrm{L}=\mathbf{0 . 8 7} \\
\mathrm{M}=\mathbf{0 . 9 0} \\
\mathrm{H}=\mathbf{1 . 0 0}\end{array}$ & $\begin{array}{l}L=0.37 \\
M=0.4 \\
H=0.7\end{array}$ & $\begin{array}{l}L=0.62 \\
M=0.68 \\
H=0.98\end{array}$ & $\begin{array}{c}\mathrm{L}=\mathbf{0 . 8 7} \\
\mathrm{M}=\mathbf{0 . 9 0} \\
\mathrm{H}=\mathbf{1 . 0 0}\end{array}$ & $\begin{array}{l}\mathrm{L}=\mathbf{0 . 3 7} \\
\mathrm{M}=\mathbf{0 . 4 0} \\
\mathrm{H}=\mathbf{0 . 7 0}\end{array}$ & $\begin{array}{l}L=0.62 \\
M=0.68 \\
H=0.98\end{array}$ & $\begin{aligned} L & =0.87 \\
M & =0.93 \\
H & =1.00\end{aligned}$ \\
\hline $\begin{array}{l}\text { Other electronic } \\
\text { artifacts, tools, } \\
\text { equipment for } \\
\text { the household }\end{array}$ & NT & 0.563 & 0.686 & 0.793 & 0.54 & 0.662 & 0.77 & 0.521 & 0.644 & 0.751 \\
\hline Electricity & NT & 1.051 & 1.111 & 1.121 & 0.784 & 0.845 & 0.855 & 0.569 & 0.63 & 0.64 \\
\hline Gas supply & IM & 0.995 & 0.995 & 0.995 & 0.995 & 0.995 & 0.995 & 0.995 & 0.995 & 0.995 \\
\hline $\begin{array}{l}\text { Basic public } \\
\text { services }\end{array}$ & NT & 1.043 & 1.248 & 1.27 & 0.896 & 1.100 & 1.122 & 0.776 & 0.981 & 1.003 \\
\hline $\begin{array}{l}\text { Repair of } \\
\text { household } \\
\text { goods }\end{array}$ & NT & 0.732 & 0.936 & 0.969 & 0.71 & 0.913 & 0.946 & 0.691 & 0.894 & 0.927 \\
\hline $\begin{array}{l}\text { Hotels, } \\
\text { restaurants }\end{array}$ & NT & 1.036 & 1.232 & 1.389 & 0.999 & 1.193 & 1.352 & 0.968 & 1.163 & 1.321 \\
\hline Transportation & NT & 0.645 & 0.79 & 0.811 & 0.593 & 0.738 & 0.759 & 0.55 & 0.696 & 0.717 \\
\hline $\begin{array}{l}\text { Mail, courier } \\
\text { services }\end{array}$ & NT & 0.541 & 0.758 & 0.938 & 0.509 & 0.725 & 0.905 & 0.482 & 0.699 & 0.879 \\
\hline $\begin{array}{l}\text { Telephone } \\
\text { services }\end{array}$ & NT & 0.877 & 1.026 & 1.059 & 0.72 & 0.868 & 0.902 & 0.593 & 0.741 & 0.775 \\
\hline $\begin{array}{l}\text { Financial } \\
\text { services }\end{array}$ & NT & 0.41 & 0.525 & 0.539 & 0.386 & 0.501 & 0.516 & 0.367 & 0.482 & 0.497 \\
\hline $\begin{array}{l}\text { Assurance, } \\
\text { reinsurance } \\
\text { services }\end{array}$ & NT & 0.706 & 0.893 & 0.918 & 0.651 & 0.838 & 0.863 & 0.607 & 0.794 & 0.819 \\
\hline $\begin{array}{l}\text { Services to } \\
\text { companies }\end{array}$ & NT & 0.570 & 0.709 & 0.728 & 0.518 & 0.656 & 0.675 & 0.475 & 0.614 & 0.633 \\
\hline $\begin{array}{l}\text { Rents } \\
\text { (apartments, } \\
\text { houses) }\end{array}$ & NT & 1.026 & 1.031 & 1.032 & 0.702 & 0.708 & 0.708 & 0.441 & 0.446 & 0.447 \\
\hline Education & NT & 0.820 & 1.066 & 1.091 & 0.793 & 1.039 & 1.064 & 0.772 & 1.018 & 1.043 \\
\hline $\begin{array}{l}\text { Medical, health } \\
\text { services }\end{array}$ & NT & 0.768 & 0.985 & 1.011 & 0.735 & 0.952 & 0.978 & 0.708 & 0.926 & 0.952 \\
\hline Entertainment & NT & 0.673 & 0.911 & 1.121 & 0.621 & 0.859 & 1.069 & 0.579 & 0.817 & 1.027 \\
\hline Other services & NT & 0.217 & 0.282 & 0.336 & 0.191 & 0.256 & 0.31 & 0.17 & 0.235 & 0.288 \\
\hline Mining & EX & 0.981 & 0.976 & 0.976 & 0.982 & 0.978 & 0.977 & 0.983 & 0.979 & 0.978 \\
\hline Construction & NT & 0.563 & 0.713 & 0.845 & 0.543 & 0.693 & 0.824 & 0.526 & 0.676 & 0.807 \\
\hline Commerce & NT & 0.553 & 0.734 & 0.87 & 0.518 & 0.699 & 0.834 & 0.489 & 0.67 & 0.806 \\
\hline $\begin{array}{l}\text { Chemical } \\
\text { industry }\end{array}$ & $\mathrm{IM}$ & 0.989 & 0.989 & 0.989 & 0.989 & 0.989 & 0.989 & 0.989 & 0.989 & 0.989 \\
\hline $\begin{array}{l}\text { Basic industry } \\
\text { metals }\end{array}$ & EX & 0.974 & 0.97 & 0.969 & 0.976 & 0.972 & 0.971 & 0.977 & 0.973 & 0.972 \\
\hline
\end{tabular}

$L=$ low-skilled labor; $M=$ medium-skilled labor $; H$ high-skilled labor, $K=$ capital,

$I M=$ importable sectors; $E X=$ exportable sectors; $N T=$ non-tradable sectors.

Source: Ahmad and Viscarra (2016). Calculations based on the input-output matrix 2008, Central Bank of Chile.

Interestingly, sensitivity to various levels of a "carbon tax" results does not change the social profitability of sectors, but results in changes within the accounting rations for each set of assumptions. ${ }^{4}$ This implies that there will be changes in the

\footnotetext{
${ }^{4}$ Simulations carried out at the request of SNI and available on request.
} 
choice of techniques within the sectoral prioritization, although the overall recommendation for diversification for more sustainable employment generation remains robust.

Many of the parameters to choose among the wide range of shadow prices will be determined by the governments medium-term macro-fiscal or sustainable growth strategy. This will help to fix the key assumptions to be used in the project selection process, including the choice of the social discount rate. In our view, greater precision is needed especially with respect to tax policy at the national and subnational levels.

\section{TABle 3}

Chile: social profitability of different sectors

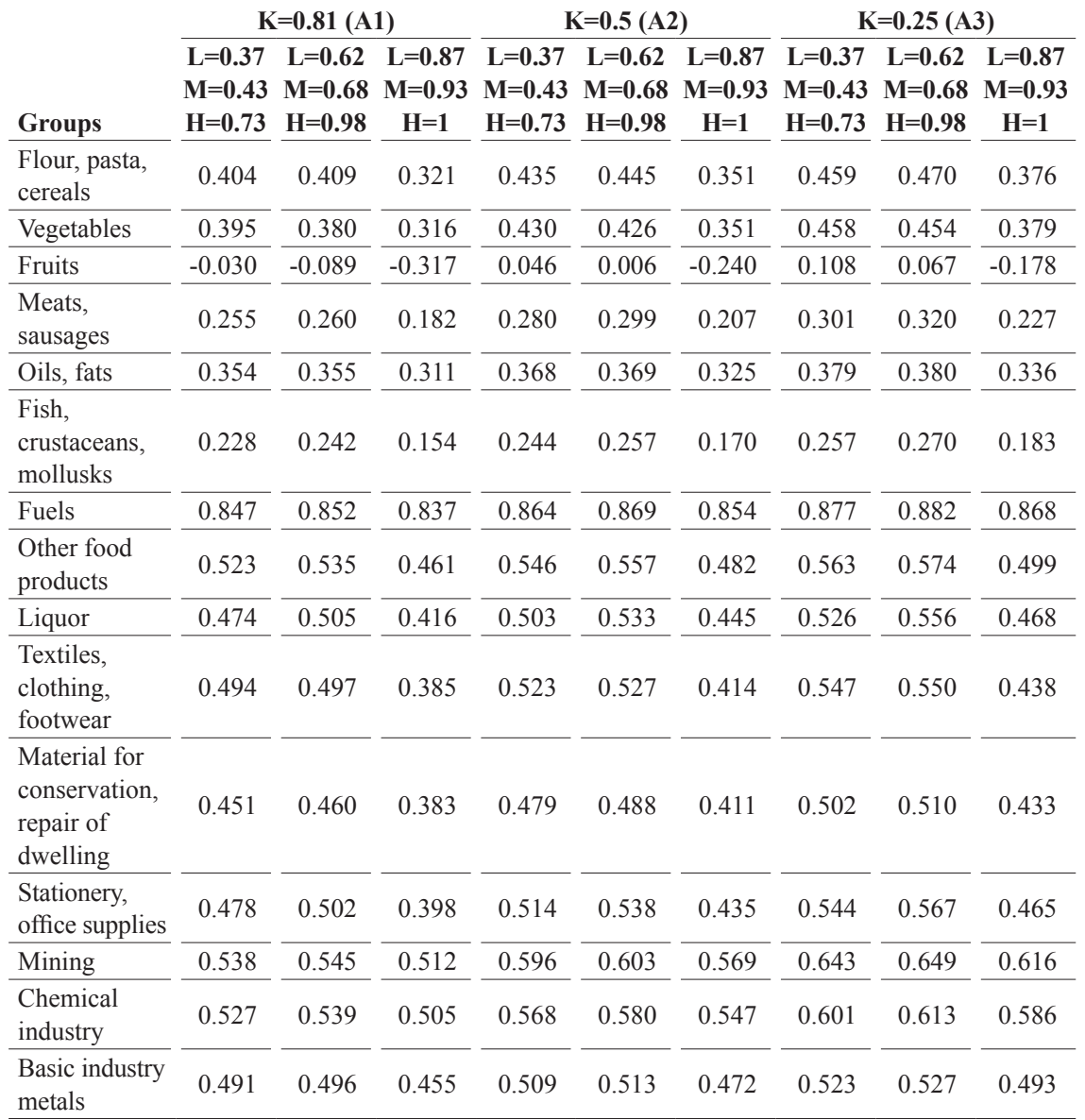

Source: Ahmad and Viscarra (2016). A number of simulations were carried out with alternative assumptions concerning the tradable and non-tradable sectors.

Ahmad and Viscarra (2016) use the theory of reform (see Ahmad and Stern, 1991) to complete the policy analysis associated with a sustainable investment strategy. 
This evaluates the social marginal cost of raising a peso/\$ on firms (through the shadow prices) and households (using a household income and expenditure survey), and are evaluated using complete demand systems (estimated by Ahmad and Viscarra, 2016) and estimated for various degrees of inequality aversion (Atkinson index, $\varepsilon$ of 0 is what is currently in place with SNI - a peso to the poorest is evaluated as the same as a peso to the richest group in the country; and Atkinson index of $\varepsilon=5$ puts almost all the weight on the lowest groups of the population. Rankings of the social marginal cost for various levels of $\varepsilon$ are shown in table 4 .

Details of the directions of reform are explained in Ahmad and Viscarra (2016). For our purposes, we illustrate how the method would work in practice. The basis of the tax system would be a VAT on all transactions that generates production efficiency - business to business transactions are credited, and exports are zerorated (all tax on earlier stages removed).

\section{TABLE 4}

Chile social marginal cost ranking for different inequality parameters

\begin{tabular}{|c|c|c|c|c|c|}
\hline Groups & $\mathrm{e}=\mathbf{0}$ & $\mathrm{e}=0.5$ & $e=1$ & $\mathrm{e}=\mathbf{2}$ & $\mathbf{e}=\mathbf{5}$ \\
\hline Rents (houses, apartments) & 1 & 1 & 1 & 1 & 1 \\
\hline Transportation & 2 & 3 & 15 & 21 & 19 \\
\hline Other services & 3 & 17 & 24 & 24 & 24 \\
\hline Education & 4 & 23 & 25 & 25 & 25 \\
\hline Telephone services & 5 & 16 & 22 & 23 & 23 \\
\hline Hotels, restaurants & 6 & 11 & 16 & 18 & 18 \\
\hline Textiles, clothing, footwear & 7 & 7 & 12 & 14 & 8 \\
\hline Health & 8 & 13 & 18 & 16 & 10 \\
\hline Meats, sausages & 9 & 5 & 4 & 6 & 9 \\
\hline Public basic services & 10 & 2 & 2 & 2 & 2 \\
\hline Financial services & 11 & 14 & 17 & 15 & 14 \\
\hline Flour, pasta, cereals & 12 & 6 & 5 & 17 & 17 \\
\hline Entertainment & 13 & 26 & 26 & 26 & 27 \\
\hline Electricity & 14 & 4 & 3 & 5 & 7 \\
\hline Vegetables & 15 & 9 & 11 & 12 & 15 \\
\hline Non-alcoholic beverages & 16 & 8 & 7 & 7 & 6 \\
\hline Pharmaceutical products & 17 & 21 & 21 & 20 & 20 \\
\hline Dairy products, cheese, eggs & 18 & 10 & 10 & 11 & 13 \\
\hline Other food products & 19 & 19 & 20 & 19 & 22 \\
\hline Gas & 20 & 12 & 8 & 10 & 12 \\
\hline Liquor & 21 & 15 & 6 & 3 & 3 \\
\hline Fruits & 22 & 18 & 13 & 8 & 5 \\
\hline Tobacco & 23 & 25 & 23 & 22 & 21 \\
\hline Toiletries, cosmetics & 24 & 27 & 27 & 27 & 26 \\
\hline Fish, crustaceans, mollusks & 25 & 20 & 9 & 4 & 4 \\
\hline Oils, fats & 26 & 22 & 14 & 9 & 16 \\
\hline Fuels & 27 & 24 & 19 & 13 & 11 \\
\hline
\end{tabular}

Source: Ahmad and Viscarra (2106). Note 1 is the highest rank social cost, and least attractive to tax and 27 the lowest rank and most attractive to raise an additional dollar in revenue. 
The required differentiation, say for tobacco and cosmetics, comes through additional excises, or in the case of fuels, a carbon tax. As seen in the first column of table 4, fuels are attractive from the perspective of the theory reform and are the most attractive sector for additional taxation. The rankings change as the Atkinson index increases, as even the poor consume fuels. However, from a sustainable development perspective, one would still want to tax carbon, and some compensation for the poor needs to be sought. This is a different situation from that pertaining to basic public services that becomes one of the least attractive sectors to tax as inequality aversion increases even slightly - the issue is discussed further in Ahmad (2017). The importance of housing and basic public services that arises from the directions of reform analysis meshes nicely with the issue of who is to provide these, especially for sustainable local "hubs".

Education might appear to be a paradoxical sector to tax. However, given the characteristics of the household income and expenditure surveys (CASEN), the poorer groups do not pay for education, whereas mainly the rich families in Chile pay fees. Subjecting the sector to a VAT, for example, would effectively zero-rate public education, whereas the private sector providing expensive fee paying instruction would be appropriately taxed. Taxation of education, consequently, would be equality enhancing.

\section{URBAN HUBS - "NEW CLEAN CITIES?"}

Chile has a huge potential to develop new clean cities or hubs, given the success it has had with renewable energy. Costs for solar energy have dropped precipitously - and in 37 winning auctions (2013-16), Chile had one of the lowest bids in the world at US 2.9 cents $/ \mathrm{kWh}$ - and this compares with 18.4 cents $/ \mathrm{kWh}$ in Indonesia, and 6.5 cents/kWh in Brazil and South Africa (Monari, 2017). This presents a huge technological advantage and could be the true "game changer". However, as with the issue of road and rail connectivity, much depends on both the tax agenda and the local service delivery needed to make new "hubs", or clean cities, feasible.

The essence of "convergence" is the faster growth of lagging regions to begin to catch up with the advanced regions in terms of per capita incomes and employment generation capabilities. This is largely driven by the private sector, although the public sector has a major role to play in relation to investments in human and physical capital. To some extent, convergence is already taking place in Chile, as we shall see below, but largely due to slowing growth rates in the Metropolitan areas - due to capacity constraints and congestion, as well as the economic slowdown since 2008 due to the international crisis. This is also a manifestation of the "middle income trap" facing Chile as well as other emerging market economies, such as China, and the challenge of maintaining sustainable growth and employment generation. Indeed, the coefficients for investment appear to change sign, potentially reflecting the continued level of relatively high public spending, offset by lower private spending and reduced effectiveness of investment. 
The role of public investments would be largely to facilitate private investment in sustainable "hubs" that reflect the comparative advantages of the country, and provides sustainable employment generation. A convergence of growth rates with sustainable development, throughout the country, clearly requires a better distribution as well as utilization of "enabling" public investments in physical and human capital. The role of the regional tier is important, and has been the basis for the current discussion in Chile (see Granados and Rodríguez, 2013).

Interior "sustainable" hubs are possible provided they optimize sources of supply (including a skilled labor force), as well as potential demand (domestic consumers as well as exports. Measures such as cash transfers to the poor may not close regional "gaps" or even reduce poverty (as in Chiapas, Mexico - see Ahmad, 2015).

Tax breaks may do little other than to create holes in the tax system that can be abused without generating sustainable private investment. Consequently, it is important to align the incentives for the private sector, as well as workers, to ensure that investments lead to sustained growth of employment opportunities without the need for continued preferences or "holes in the tax system" that lead to cheating.

\section{WHERE TO PUT THE HUBS?}

One can think of the current Chilean growth strategy as concentrated in the Metropolitan areas and the ports - for simplicity let's call them $A$. Given existing transport links, $f$, the furthest peripheral areas $P$ (at distance $f$ from $A$ ), are also able to utilize the export and demand patters generated by $A$. This leaves the extreme periphery $P_{N}$, or the zonas rezagadas, as unable to connect either to markets or domestic or external supply chains.

A characteristic of $P_{N}$ is that the infrastructure gaps are binding. Consequently, giving a tax holiday will lead to a perpetual subsidy, but may not be enough to ensure that the private sector will have an incentive to invest there. Similarly, a cash transfer to the poor in $P_{N}$ likely means that they will migrate to the metropolitan areas, $A$, in search of work, as there is not much to be had in and around $P_{N}$.

New "sustainable growth hubs" would typically focus on regional comparative advantage - and as mentioned above, this has changed significantly with the breakthrough in cheap and clean solar energy. This is also a function of both availability of requisite skills, as well as wider connectivity to domestic and external markets or suppliers, as well as local connectivity to the hinterland - this would be in diversified industries benefitting from cheap energy, agriculture or as in Chile's case, tourism. Consequently, the nature of the hubs will vary according to the relevant endowments.

Investment in human capital and infrastructure will change the endowments, as well as perceptions by the private sector. Some of the "hubs" may be in the remote regions - i.e., beyond the zone $P$, serviced by the main metropolitan/export hubs 
$A$, and thus opening the disadvantaged zone $P_{N}$. In Chile, addressing most of the backward zones may well involve such "hubs" in the interior.

It should be noted that given the topological constraints in Chile, the objectives of sustainable growth might also include "hubs" that are closer to the existing production/export zones $A$ than to $P_{N}$, but may nonetheless extend the reach of the markets to $P_{N}$. An example of such an "intermediate hub" is Querétaro, which has a first-rate university, and this has generated hi-tech industries including aerospace. It is a relatively small town, without the congestion and pollution of Mexico City, and its excellent transport linkages ensure that both workers and products contribute to the growing supply chains.

The placement of investments is in turn a function of project selection methods. There is the case of the famous Chacao Channel Bridge that was initiated under the Ricardo Lagos regime to open Chiloé Island, but later cancelled as the costbenefit analysis indicated insufficient demand and traffic. However, the demand itself is a function of the bridge, and past trends would not have been appropriate as an indicator of future demands. This brings us back to the issue of choice of techniques, and social cost benefit analysis in determining how resources are to be allocated.

Of course, true convergence is only established if the private sector responds effectively as production costs for producers are reduced with improvement in connectivity. Typically, measures to reduce the cost-differential would be accompanied by taxes and regulations that create incentives to move out of congested and polluted areas.

\section{POLICY IMPLICATIONS}

The discussion of the investment story in Chile, together with the evidence from the EU and China, suggests the following lessons for other emerging market economies:

1) Investment in connectivity is a necessary although not sufficient condition for creating a level playing field and generating sustainable and inclusive growth.

2) There is a need for coordinated policy actions (see chart 1) that links investment design to tax policy, local urban hubs/clean cities; and effective provision of public services.

3) Investment priorities, with economy-wide shadow prices linked to a sustainable growth strategy, are the starting point for the overall policy framework.

4) Investment priorities should be supplemented by a national tax policy framework, and we have already identified both a VAT and a carbon tax as elements that provide financing, reduce distortions and create the right incentives for public action. China has completed the full integration of the VAT on goods and services in 2016 to reduce the costs of doing business - and India is trying to do the same (with a recently passed Constitutional Amendment). 
5) The national tax agenda needs to be supplemented by a local tax system. As in the case of China or South Asia, a higher carbon tax might be justified in the Metropolitan areas that are subject to congestion and pollution - and this could be achieved with a piggy-back on the national tax (Ahmad and Stern, 2011).

The need for a local tax system, even if relatively small in terms of the overall revenues generated, is quite significant at the local level in influencing incentives facing firms, workers and most importantly, creating hard-budget constraints for local governments. The property tax does not function well at the local level in most emerging market economies, and the generation of alternative mechanisms for emerging market economies is an important ingredient in a sustainable investment agenda (Ahmad, Brosio and Pöschl, 2015; and Ahmad and Brosio, 2017 for an application to Sénégal).

6) Own-source revenues are needed at the local level also to anchor local access to credit. Without some local control over rates (e.g., within a band set by the National legislature in unitary countries - see Ahmad, 2017 for a discussion of China), it would be highly premature to create a local bond market, that would however be very helpful in due course.

\section{Chart 1}

Investment and multilevel taxation linkages

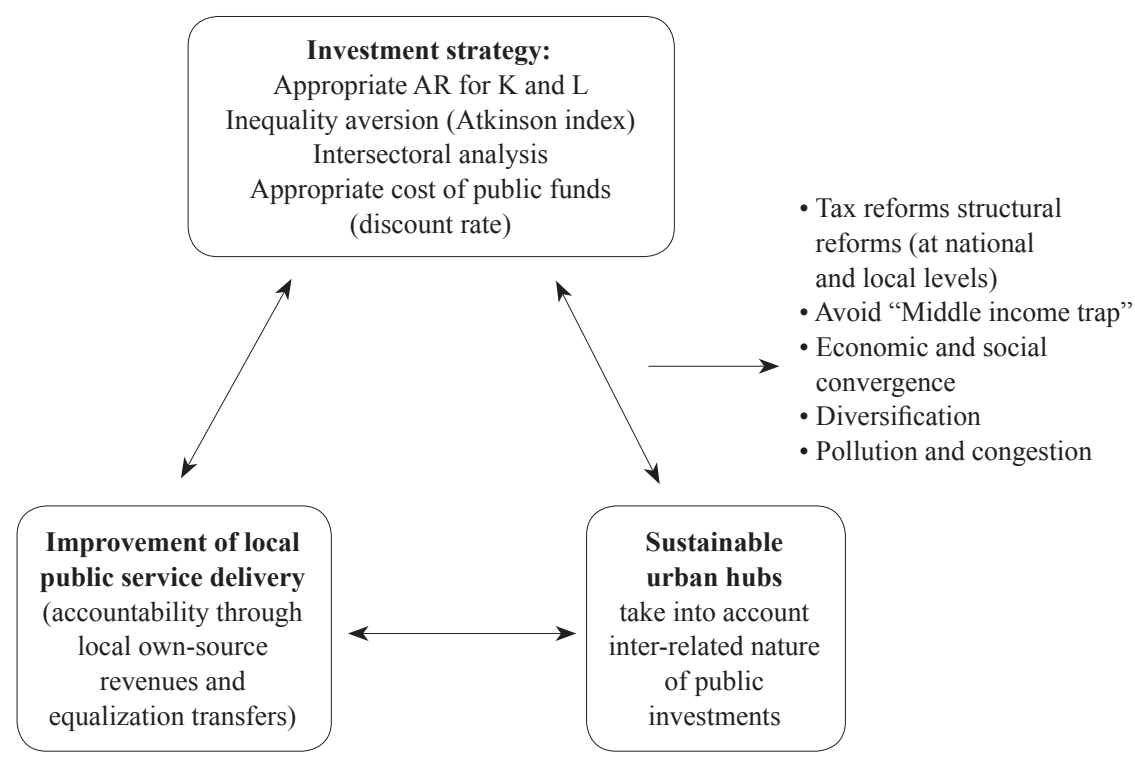

Coordination of policies across levels of governments and economic sectors 


\section{REFERENCES}

1. Ahmad, E. and Brosio, G., 2017. Sénégal: Property taxes for sustainable development. EC processed, March 2017.

2. Ahmad, E. and Stern, N., 1984. The theory of reform and Indian indirect taxes. Journal of Public Economics, (25), pp. 259-298.

3. Ahmad, E. and Stern, N., 1991. Theory and Practice of Tax Reforms in Developing Countries. Cambridge: Cambridge University Press.

4. Ahmad, E. and Stern, N., 2011. "Effective Carbon Taxation and Public Policy Actions" in M. G. Rao and M. Rakshit, eds. Public Economics: Essays in Honour of Amaresh Bagchi. Sage Press.

5. Ahmad, E. and Viscarra, H., 2016. Public Investment for Sustainable Development in Chile - building on the National Investment System. Inter-American Development Bank Discussion Paper, IDB-DP-469.

6. Ahmad, E. and Wang, Y., 1991. Inequality and poverty in China: Institutional change and public policy, 1978 to 1988. The World Bank Economic Review, 5(2), 231-258.

7. Ahmad, E. and Zhang, X., 2017. "Towards Monitoring and Managing SubNational Liabilities in China: lessons from the Balance Sheet of County K" in E. Ahmad, M. Niu and K. Xiao, eds. Sustainable Development in China Case of Guangdong. Sun-Yat Sen University (forthcoming).

8. Ahmad, E., 2015. "Governance and Institutions" in E. Ahmad and G. Brosio, eds. Handbook of Multilevel Finance. Cheltenham, UK: Edward Elgar.

9. Ahmad, E., 2017. Political economy of tax reforms in emerging market countries, G24 Processed, April 2017.

10. Ahmad, E., Bordignon, M. and Brosio, G. (eds.), 2016. Multi-level finance and the Euro crisis. Causes and Effects. Cheltenham, UK; Northampton, MA, USA: Edward Elgar Publishing.

11. Ahmad, E., Brosio, G. and Pöschl, C., 2015. "Local Property Taxation and Benefits in Developing Countries - Overcoming P Xiaorong Zhang political Resistance?" in E. Ahmad and G. Brosio. Handbook of Multilevel Finance. Cheltenham, UK: Edward Elgar. doi: 10.4337/9780857932297.00022

12. Ahmad, E., Letelier, L. and Ormeño, H., 2015. Design of transfers in Chile achieving effective service delivery and convergence of opportunities. Joint CEPAL-IADB Jornadas, Santiago de Chile.

13. Ambrosanio, F., Balduzzi, P. and Bordignon, M., 2016. "Economic crisis and fiscal federalism in Italy" in E. Ahmad, M. Bordignon and G. Brosio, eds. Multi-level Finance and the Euro Crisis: causes and Effects. doi: 10.4337/ 9781784715113.00017

14. Drèze, J. and Stern, N., 1987. "The Theory of Cost-Benefit Analysis" in A. J. Auberbach and M. Feldstein. Handbook of Public Economics. North-Holland: Elsevier Science Publishers B.V.

15. Government of Chile, 2016. National Investment System Legal Framework. Available at: <http://sni.ministeriodesarrollosocial.gob.cl/quienes-somos/ marco-legal/>. 
16. Granados, S. and Rodríguez, J., 2013. Nueva Agenda Regional: Propuestas para avanzar en decentralización fiscal en Chile. Mimeo.

17. Hausman, R. [et al.], 2013. Atlas of Economic Complexity. Harvard: Massachusetts Institute of Technology: Center for International Development.

18. IMF, 2013. IMF Staff Report. Washington DC: IMF.

19. IMF, 2016. Chile - Article IV Consultation Report, December, CR 1637.

20. Lagos, R., 2016. The Wealth Problem. Latin Finance (interview). Available at: $<$ http://www.latinfinance.com/Article/3249901/Ricardo-Lagos-The-wealthproblem.html>.

21. Levy, S., 2008. Good Intentions Bad Outcomes. Washington, DC: Brookings Institution.

22. Little, I. and Mirrlees, J., 1974. Project Appraisal and Planning for Developing Countries. London: Heinemann.

23. Monari, L., 2017. World Bank and Transformational Engagements, G24. Processed, February 2017.

24. OECD, 2013. Chile Urban Policy Review. Paris: OECD.

25. World Bank, 2006. Chile Public Investment Management Review. Washington DC: The World Bank. 